\title{
sciendo
}

Current Issues in Pharmacy and Medical Sciences

Formerly ANNALES UNIVERSITATIS MARIAE CURIE-SKLODOWSKA, SECTIO DDD, PHARMACIA

journal homepage: http://www.curipms.umlub.pl/

\section{Influence of chromium (III), cobalt (II) and their mixtures on cell metabolic activity}

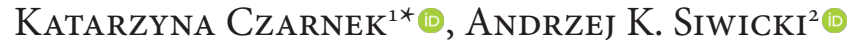 \\ ${ }^{1}$ Institute of Health Sciences, Faculty of Science and Health Sciences in Lublin, The John Paul II Catholic University of Lublin, Poland \\ 2 Department of Microbiology and Clinical Immunology, Faculty of Veterinary Medicine, University of Warmia and Mazury in Olsztyn, \\ Poland
}

\begin{tabular}{l}
\hline ARTICLE INFO \\
\hline Received 12 March 2021 \\
Accepted 15 May 2021
\end{tabular}

Keywords:

cobalt,

chromium,

toxicity,

interaction.

\begin{abstract}
Chromium (III) and cobalt (II) are necessary elements required for the proper functioning of the organism, but their excess can cause toxic effects. They are the basic components of implants and are also commonly used in medicine as components of dietary supplements, vitamin and mineral products and energy drinks. The aim of this study was to investigate the effect of cobalt (II) and chromium (III) and their combination on BJ cells. In the study, $\mathrm{BJ}$ cells were exposed to $\mathrm{CoCl}_{2}$ or $\mathrm{CrCl}_{3}$ at concentrations ranging from 100 to $1400 \mu \mathrm{M}$, and the cytotoxicity of chromium (III) and cobalt (II) and their mixtures was assessed by MTT reduction, LDH release and NRU assays. The outcome of this work reveals the cytotoxic effects of chromium (III) and cobalt (II) and their mixtures on BJ cells. In the cytotoxicity assays, at low concentrations of $\mathrm{CoCl}_{2}$ and $\mathrm{CrCl}_{3}$, stimulation of cell proliferation was observed. In higher concentrations, the cell viability decreased for the tested line in all the assays. During the simultaneous incubation of fibroblasts with $200 \mu \mathrm{M}$ of $\mathrm{CrCl}_{3}$ and $1000 \mu \mathrm{M}$ of $\mathrm{CoCl}_{2}$, antagonism was observed: chromium (III) at the concentration of $200 \mu \mathrm{M}$ induced protection from cobalt (II) toxicity; in the case of interaction of chromium chloride at $1000 \mu \mathrm{m}$ and cobalt chloride at $200 \mu \mathrm{M}$, the protective effect of $\mathrm{CrCl}_{3}$ on $\mathrm{CoCl}_{2}$ was not observed. In the latter case, synergism between these elements was noted. Our work indicates that cobalt (II) and chromium (III) show cytotoxic properties. These metals have a destructive effect on the cell membrane, lysosomes and mitochondria, which leads to disorders of cell metabolism.
\end{abstract}

\section{INTRODUCTION}

Cobalt (II) and chromium (III) play crucial roles in human and animal body homeostasis [1]. Cobalt (II) is a microelement which is widespread in the environment. This element is very important due to its function in the biological system. This micronutrient is required in the form of vitamin $\mathrm{B}_{12}$ (hydroxycobalamin) in human diets. This vitamin plays a very important role in forming amino acids and some proteins in nerve cells and creating neurotransmitters which are indispensable for correct functioning of the organism [2-5]. Cobalt occurs in various oxidation states, i.e. $0,+2,+3,+4$, but the most common are +2 and $+3[6,7]$. Moreover, cobalt (II) is present in bacterial metalloenzymes as methionine aminopeptidase, and its functioning depends on cobalt [8].

\footnotetext{
* Corresponding author

e-mail: kczarnek@kul.pl
}

Epidemiological and laboratory studies report that cobalt and its compounds are carcinogenic to humans and are included in group 2 by International Agency for Research on Cancer [6,9-10]. Exposure to cobalt metal, its salts or heavy metal causes genotoxic and cytotoxic effects in many cells. The cytotoxicity of cobalt ions has been reported in many cell types and it can induce cell death by apoptosis and necrosis [2]. Cobalt (II) is capable of inducing oxidation and nitrification of proteins which lead to damage of cellular compartments in cells [11]. What is more, some studies report that cobalt induces chromosome aberrations, sister chromatide exchanges and single and double strand breaks $[11,12]$. This metal is able to generate active oxygen species (ROS) that are very destructive in the DNA and other biomolecules $[11,13]$. Moreover, cobalt (II) destabilizes the proper functioning of enzymes belonging to the antioxidant system, such as superoxide dismutase (SOD), catalase (CAT) and glutathione peroxidise (GPx). Additionally, cobalt (II) 
can bind to zinc and copper sites in SOD, thus lowering the enzyme activity [14]. In addition, the element may interfere with the proper functioning of the zinc finger domain of the XPA protein, which is active in the process of nucleotide excision during the repair of mutated DNA [11].

The replacement of zinc with cobalt (II) in the XPA protein promotes the formation of ROS near the DNA, which affects its destruction [15]. Cobalt (II) disrupts the proper functioning of topoisomerase II (which requires divalent cations to carry out DNA cleavage) by forming complexes with this enzyme [11]. In addition, literature data show that cobalt (II) competes with zinc ions, which may affect the efficiency of the $\mathrm{p} 53$ protein binding mechanism to DNA, which is dependent on the presence of these ions $[16,17]$.

Chromium (III) occurs naturally in the environment and is the most common and stable form found in living organisms. This element is characterized by low reactivity, which is extremely important in biological systems [18-21]. Chromium (III) is involved in carbohydrate, lipid and protein metabolism. It is very important for normal functioning of the insulin receptor, which is an integral component of glucose tolerance factor [20,22]. This element occurs in the environment in various degrees of oxidation - ranging from -2 to +6 . However, in chemical compounds it is found at $+1,+2,+3$ and +6 degrees, and exceptionally at +4 and +5 . Chromium with a zero oxidation state does not occur naturally in the Earth's crust and is biologically inert [18,23].

The hexavalent form is associated with the toxic effect on organism and is classified as a human carcinogen and mutagen [20]. Chromium(VI) in the cell is reduced by the redox system, which leads to the formation of various forms, including the trivalent one [26]. Chromium (III) has a destructive effect on the antioxidant system, which is unable to remove harmful oxygen species under conditions of disturbed cellular equilibrium. The activity of the superoxide dismutase enzymes, glutathione peroxidase, gradually decreases under the influence of ROS, which leads to irreversible destructive changes, i.e. lipid peroxidation and the formation of malondialdehyde [24-26]. As reported in the literature, chromium(III) and its compounds are toxic and cause formation of DNA-DNA crosslink and singlestrand breaks. Some disturbance in metabolism of oxygen and depletion of ATP level has also been noted [26].

Living organisms are constantly exposed to chromium and cobalt because these elements are widely used in the metallurgical, aerospace, electronic and tool industries $[27,28]$. Moreover, they are the fundamental components of implants commonly used in medicine. Nowadays, modern medicine offers dietary supplements and vitamins that are widely consumed globally [29-33]. Cobalt (II) is a component of many dietary supplements; manufacturers recommend its consumption in the amount of $1 \mathrm{mg}$ Co per day, in order to ensure proper metabolism of fats and sugars, protein synthesis and the production of red blood cells. In addition, some energy drinks also contain cobalt, which is found in the form of cyanocobalamin. This metal is present in significant amounts, about $41.677 \%$, corresponding to about $100 \mu \mathrm{g}$ of cobalt per serving at the FDA (Food and Drug Administration) recommended dosage of only $6 \mu \mathrm{g}$ [34].
Chromium (III) is also a component of many dietary supplements, most often in the form of chromium picolinate - which reduces the fatty acid content [35-38]. Moreover, cocktails and supplements for athletes are often spiked with chromium (III) and are very often self-administered to reduce body fat, increase the body $>\mathrm{s}$ aerobic capacity and to achieve better training results [34].

Thus, these metals can enter the body in a variety of ways. In high concentrations, they can be potentially toxic to cells and can cause a number of changes at the cellular level. Despite many reports, the metabolism of chromium (III) and cobalt (II) is not well-known and the interactions between these elements are unknown. Bearing in mind the importance of both elements, the aim of the present work was to determine the influence of chromium (III) and cobalt (II) and their mixtures on cell organelles. Additionally, it aimed at determining the relationships between these elements.

\section{MATERIALS AND METHODS}

The research was carried out on human fibroblast BJ cell lines, obtained from American Type Culture Collection (ATCC). The cells were grown as adherent monolayers in Eagle's Minimum Essentials Medium (EMEM), supplemented with $10 \%$ fetal bovine serum (FBS) obtained from ATCC, and antibiotic antimycotic solution $(10.000 \mathrm{U} / \mathrm{ml}$ of penicillin, $10 \mathrm{mg} / \mathrm{mL}$ of streptomycin, $25 \mu \mathrm{g} / \mathrm{mL}$ of amphotericin $\mathrm{B}$ ), at $37^{\circ} \mathrm{C}$ and $5 \% \mathrm{CO}_{2}$. Hexahydrate chromium chloride $\left(\mathrm{CrCl}_{3} \times 6 \mathrm{H}_{2} \mathrm{O}\right)$ and hexahydrate cobalt chloride $\left(\mathrm{CoCl}_{2} 6 \mathrm{H}_{2} \mathrm{O}\right)$ were dissolved in Phosphate Buffered Saline (PBS) to concentration of $1 \mathrm{mM}$. Solutions of chromium chloride or cobalt chloride at the concentration range from 100 to $1400 \mu \mathrm{M}$ were prepared by diluting them in culture medium EMEM supplemented with FBS and antibiotics.

\section{Cytotoxic assays}

In vitro cytotoxicity assays are commonly used to indicate cytotoxic effects induced by chemicals in different compartments of cells. In our work, these methods allow determining cell viability assessment by measuring the number of cells, dead or alive, after exposure to chromium chloride or cobalt chloride [40]. All cytotoxic assays detect very specific changes in different cell organelles that occur after exposure to toxic substances. In this work, the 3-[4,5-dimethylthiazol2-yl]-2,5-diphenyltetrazolium bromide (MTT) reduction, the neutral red uptake (NRU) and lactate dehydrogenase (LDH) cytotoxicity assays were used. All the assays were performed according to the original manufacturer's instructions - In vitro Toxicology Assay Kit, Sigma Aldrich (MTT - TOX-1; LDH - TOX-7; NR - TOX-4).

The cells were cultured in 96 -well plates $\left(2 \times 10^{5} \mathrm{cells} / \mathrm{mL}\right)$ in $100 \mu \mathrm{L}$ in complete growth medium (EMEM supplemented with $10 \%$ FBS and mixture of antibiotics). After 24-hour incubation of fibroblast, the culture fluid was exchanged into a new one in the control case or supplemented with chromium chloride or cobalt chloride at concentrations ranging from 100 to $1400 \mu \mathrm{M}$. In order to determine the interactions between the above-mentioned microelements, the cells were similarly plated and incubated for 24 hours. In the next phase, the culture fluid was changed into a 
fresh one and supplemented with mixture compounds with the following combinations: $200 \mu \mathrm{M}$ chromium chloride and $1000 \mu \mathrm{M}$ cobalt chloride or $1000 \mu \mathrm{M}$ chromium chloride and $200 \mu \mathrm{M}$ cobalt chloride. Subsequently, MTT, LDH and NRU assays were performed. The cultures were then subjected to spectrophotometric analysis.

The percentage of cell viability was calculated by relating the absorbance values obtained for each concentration of the tested compounds to the absorbance value of the control cells, taking the absorbance of the solution for the control cells as $100 \%$ (in the case of the MTT and NRU assays). In the LDH assay, the percentage of LDH release was calculated $(\%$ release $\mathrm{LDH}=$ amount of spontaneously released LDH from the cell into the culture fluid/amount of total LDH spontaneously released and remaining in the cell $\times 100 \%$ ). A dose-response curve was then prepared for each of the compounds tested, and the $\mathrm{IC}_{50}$ value was determined.

\section{Statistics}

The results were analyzed using one-way analysis of variance (ANOVA) with Tukey's multiple comparisons, using Statistica version 4.0.

\section{RESULTS}

In the cytotoxic assays at low concentrations of both tested compounds, stimulation of cell proliferation was observed. However, in higher concentrations, the cell viability decreased. Additionally, an increase in release of lactate dehydrogenase in the LDH assay in the case of both tested compounds was observed. Cytotoxic effects of chromium chloride and cobalt chloride are shown in Figures 1, 2 and 3. After incubation of the BJ cells with chromium chloride in the concentration range of 100 and $200 \mu \mathrm{M}$, an increase in cell viability, which was approximately $10 \%$ at the concentration of $100 \mu \mathrm{M}$, was noted. In the concentrations ranging from 1000 to $1400 \mu \mathrm{M}$, a statistically significant decrease in cell viability as compared to the control cells was observed. Incubation of cells with cobalt chloride caused a statistically significant decrease in cell viability at concentrations of $400 \mu \mathrm{M}$ and more, along with the increasing concentrations, as compared to the control system. An increase in cell proliferations was observed only at the lowest concentration. The above-mentioned cytotoxic effects were observed in the MTT assay.

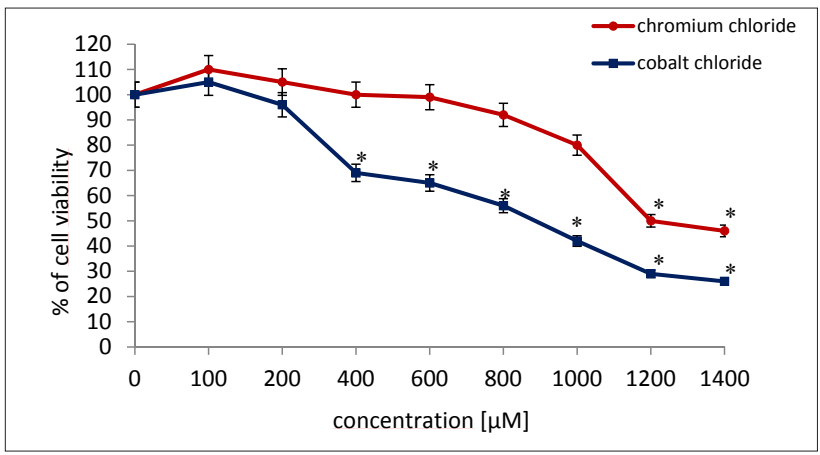

* significance of difference compared with control $\mathrm{p} \leq 0.05$

Figure 1. Cytotoxic effect of $\mathrm{CrCl}_{3} \times 6 \mathrm{H}_{2} 0$ or $\mathrm{CoCl}_{2} \times 6 \mathrm{H}_{2} 0$ in the $\mathrm{BJ}$ line - as detected via the MTT assay
In the LDH assay, a statistically significant increase in release of enzyme (decreased cell viability), along with an increase in the concentration of the tested compound, compared to the control was observed.

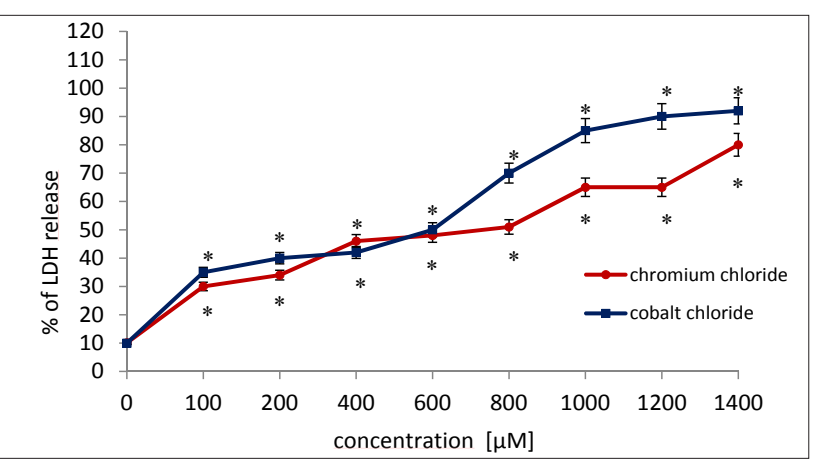

* significance of difference compared with control $p \leq 0.05$

Figure 2. Cytotoxic effect of $\mathrm{CrCl}_{3} \times 6 \mathrm{H}_{2} 0$ or $\mathrm{CoCl}_{2} \times 6 \mathrm{H}_{2} 0$ in the $\mathrm{BJ}$ line - as detected via the $\mathrm{LDH}$ release assay

An analysis of the graph in the NRU assay reveals that after incubating the BJ cells with chromium chloride at concentrations of 100 and $200 \mu \mathrm{M}$, a slight increase in cell viability, as compared to the control, was observed.

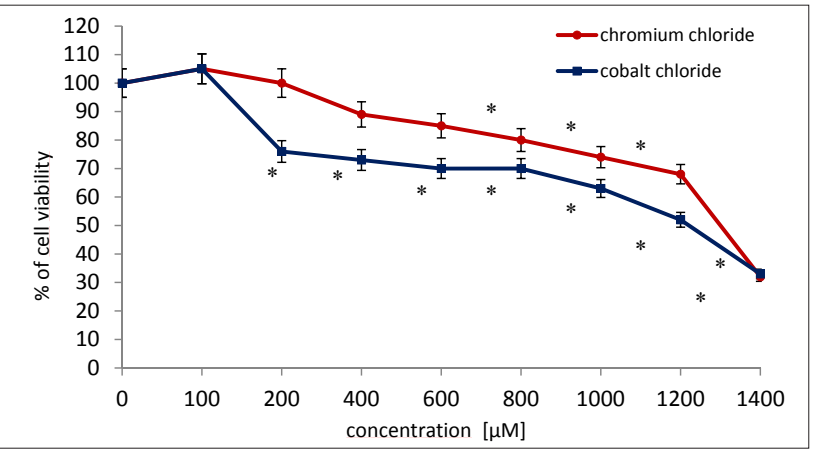

* significance of difference compared with control $p \leq 0,05$

Figure 3. Cytotoxic effect of $\mathrm{CrCl}_{3} \times 6 \mathrm{H}_{2} 0$ or $\mathrm{CoCl}_{2} \times 6 \mathrm{H}_{2} 0$ in the BJ line - as detected via the NRU assay

A statistically significant decrease in cell viability at the concentration of $800 \mu \mathrm{M}$ for the human fibroblasts was also noted. The same results were received after incubation of human fibroblast cell lines with cobalt chloride. For each test, the value $\mathrm{IC}_{50}$ was determined (Table 1).

Table 1. $\mathrm{IC}_{50}$ values for the $\mathrm{BJ}$ line following exposure to $\mathrm{CrCl}_{3}$ $\times 6 \mathrm{H}_{2} 0$ and $\mathrm{CoCl}_{2} \times 6 \mathrm{H}_{2} 0-$ as determined in cytotoxicity assays

\begin{tabular}{|c|c|c|c|}
\hline Tested compounds & MTT & LDH & NRU \\
\hline $\mathrm{CrCl}_{3} \times 6 \mathrm{H}_{2} \mathrm{O}$ & $1200 \mu \mathrm{M}$ & $800 \mu \mathrm{M}$ & $1250 \mu \mathrm{M}$ \\
\hline $\mathrm{CoCl}_{2} \times 6 \mathrm{H}_{2} \mathrm{O}$ & $900 \mu \mathrm{M}$ & $600 \mu \mathrm{M}$ & $1200 \mu \mathrm{M}$ \\
\hline
\end{tabular}

MTT - the MTT reduction assay

$\mathrm{LDH}$ - the $\mathrm{LDH}$ release assay

NRU - the neutral red uptake assay

On the basis of the results obtained at the first stage of the research, the concentrations of the elements were selected in order to determine the interactions between them. The BJ cells were treated with the mixtures of the following compounds: $200 \mu \mathrm{M}$ chromium chloride and $1000 \mu \mathrm{M}$ cobalt chloride or $1000 \mu \mathrm{M}$ chromium chloride and $200 \mu \mathrm{M}$ cobalt chloride. During the simultaneous incubation with chromium chloride at the concentration of $200 \mu \mathrm{M}$ and cobalt chloride at the concentration of $1000 \mu \mathrm{M}$ of the BJ cells, a statistically significant decrease in cell viability 
was noted when compared to the control cells and those incubated with chromium chloride at the concentration of $200 \mu \mathrm{M}$, while as to the cells incubated only with cobalt chloride at the concentration of $1000 \mu \mathrm{M}$, a statistically significant increase in cell viability was observed. In the case of simultaneous incubation of fibroblast with chromium chloride at the concentration of $1000 \mu \mathrm{M}$ and cobalt chloride at the concentration of $200 \mu \mathrm{M}$, a decrease in cell viability was noted, but not statistically significant when compared to the cells incubated only with cobalt chloride at the concentration of $200 \mu \mathrm{M}$. Compared to the cells incubated only with chromium chloride at the concentration of $1000 \mu \mathrm{M}$, no changes in viability of human fibroblasts were noted. The effect of mixtures of chromium chloride and cobalt chloride on viability of cells in the MTT assay is shown in Figure 4. In the next assay, simultaneous incubation of cells with $200 \mu \mathrm{M}$ chromium chloride and $1000 \mu \mathrm{M}$ cobalt chloride decreased lactate dehydrogenase release compared to cells incubated only with $200 \mu \mathrm{M}$ chromium chloride or $1000 \mu \mathrm{M}$ cobalt chloride.

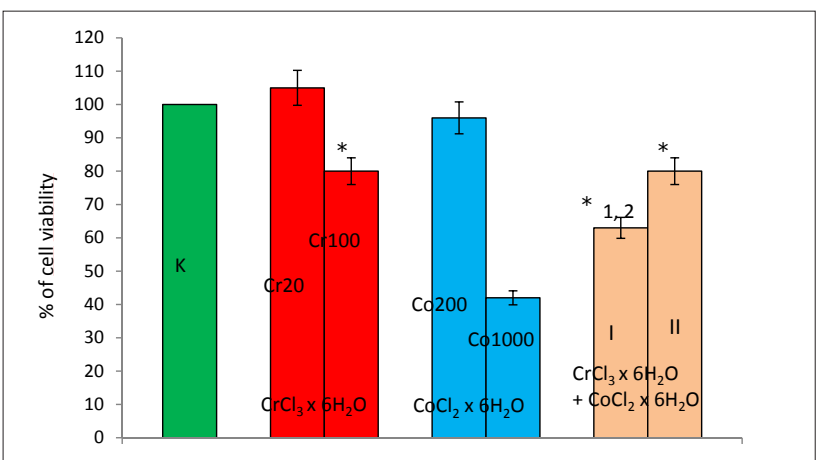

$\mathrm{K}$ - Control, I: simultaneous incubation with $\mathrm{CrCl}_{3} \times 6 \mathrm{H}_{2} \mathrm{O}$ at concentration of $200 \mu \mathrm{M}+\mathrm{CoCl}_{2} \times 6 \mathrm{H}_{2} \mathrm{O}$ at concentration of $1000 \mu \mathrm{M}$. II: $\mathrm{CrCl}_{3} \times 6 \mathrm{H}_{2} \mathrm{O}$ at concentration of $1000 \mu \mathrm{M}+\mathrm{CoCl}_{2} \times 6 \mathrm{H}_{2} \mathrm{O}$ at concentration of $200 \mu \mathrm{M}$ * - significance of difference compared with control $p \leq 0.05,1$ - significance of difference compared with chromium chloride at concentration of $200 \mu \mathrm{M}$ 2 - significance of difference compared with cobalt chloride at concentration of $1000 \mu \mathrm{M}$

Figure 4. Effect of mixtures of chromium chloride and cobalt chloride on cell viability of the BJ lines in the MTT reduction assay

However, in the case of simultaneous incubation of chromium chloride at the concentration of $1000 \mu \mathrm{M}$ and cobalt chloride at the concentration of $200 \mu \mathrm{M}$ of fibroblast cell line, a statistically significant increase in the release of enzyme lactate dehydrogenase was noted when compared to control cells and incubated only with chromium chloride at the concentration of $1000 \mu \mathrm{M}$ or only with cobalt chloride at the concentration of $200 \mu \mathrm{M}$ (Fig. 5).

Figure 6 shows the results obtained in the NRU assay. During simultaneous incubation with chromium chloride at the concentration of $200 \mu \mathrm{M}$ and cobalt chloride at the concentration of $1000 \mu \mathrm{M}$ of the BJ cells, there was a statistically significant decrease in cell viability when compared to the control cells and incubated only with chromium chloride at the concentration of $200 \mu \mathrm{M}$, while a statistically significant increase in cell viability compared to cells incubated only with $1000 \mu \mathrm{M}$ cobalt chloride, and an increase in cell viability were noted. However, in the case of simultaneous incubation of chromium chloride at the concentration of $1000 \mu \mathrm{M}$ and cobalt chloride at the concentration of $200 \mu \mathrm{M}$ of fibroblast lines, a statistically significant decrease in cell viability was observed when compared to control cells and incubated only with chromium chloride at the concentration of $1000 \mu \mathrm{M}$ or cobalt chloride at the concentration of $200 \mu \mathrm{M}$.

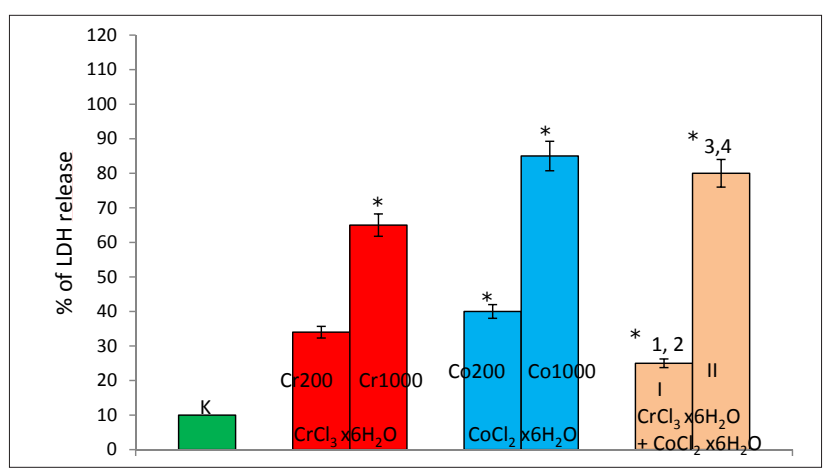

$\mathrm{K}$ - Control, I: simultaneous incubation with $\mathrm{CrCl}_{3} \times 6 \mathrm{H}_{2} \mathrm{O}$ at concentration of $200 \mu \mathrm{M}+\mathrm{CoCl}_{2} \times 6 \mathrm{H}_{2} \mathrm{O}$ at concentration of $1000 \mu \mathrm{M}$. II: $\mathrm{CrCl}_{3} \times 6 \mathrm{H}_{2} \mathrm{O}$ at concentration of $1000 \mu \mathrm{M}+\mathrm{CoCl}_{2} \times 6 \mathrm{H}_{2} \mathrm{O}$ at concentration of $200 \mu \mathrm{M}$, * - significance of difference compared with control $p \leq 0.05,1$ - significance of difference compared with chromium chloride at concentration of $200 \mu \mathrm{M}$, of difference compared with chromium chloride at concentration of $200 \mu \mathrm{M}$, 2 - significance of difference compared with cobalt chloride at concentration of $1000 \mu \mathrm{M}, 3-$ significance of difference compared with chromium chloride at
concentration of $1000 \mu \mathrm{M}, 4$ - significance of difference compared with cobalt chloride at concentration of $200 \mu \mathrm{M}$

Figure 5. Effect of mixtures of chromium chloride and cobalt chloride on cell viability of the $\mathrm{BJ}$ lines in the LDH release assay.

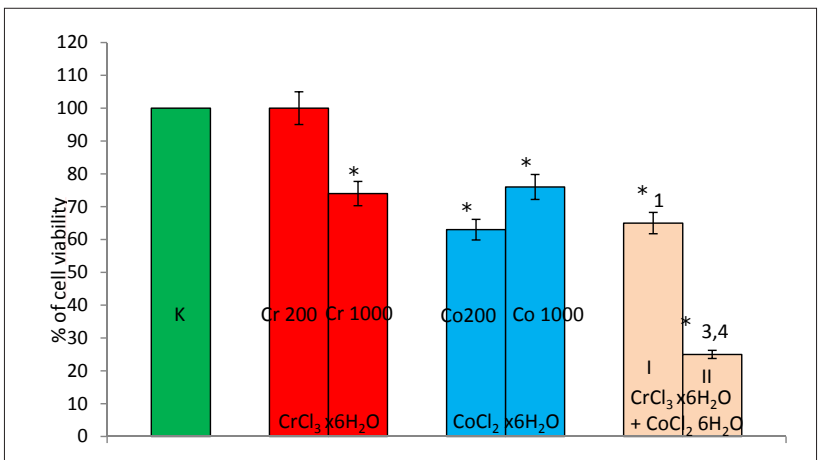

$\mathrm{K}$ - control, I: simultaneous incubation with $\mathrm{CrCl}_{3} \times 6 \mathrm{H}_{2} \mathrm{O}$ at concentration of $200 \mu \mathrm{M}+\mathrm{CoCl}_{2} \times 6 \mathrm{H}_{2} \mathrm{O}$ at concentration of $1000 \mu \mathrm{M}$. II: $\mathrm{CrCl}_{3} \times 6 \mathrm{H}_{2} \mathrm{O}$ at concentration of $1000 \mu \mathrm{M}+\mathrm{CoCl}_{2} \times 6 \mathrm{H}_{2} \mathrm{O}$ at concentration of $200 \mu \mathrm{M}$, $*$ - significance of difference compared with control $\mathrm{p} \leq 0.05 ; 1$ - significance of difference compared with chromium chloride at concentration of $200 \mu \mathrm{M}$, 2 - significance of difference compared with cobalt chloride at concentration of $1000 \mu \mathrm{M}, 3$ - significance of difference compared with chromium chloride at concentration of $1000 \mu \mathrm{M}, 4$ - significance of difference compared with cobalt chloride at concentration of $200 \mu \mathrm{M}$

Figure 6. Effect of mixtures of chromium chloride and cobalt chloride on cell viability of the BJ lines in the NR uptake assay.

\section{DISCUSSION}

The cytotoxic activity of the elements can be assessed by direct or indirect measurement of changes in the cells that are exposed to some chemicals when compared to the control system. By using properly selected assays, it is possible to determine the efficiency of individual cell organelles. The MTT assay allows determining the efficiency of the key cell organelle, which is the mitochondria, it also detects perturbations and their functions. The NRU assay detects loss of lysosomal activity on cells and the LDH release assay detects the loss of cell membrane integrity. After analyzing the $\mathrm{IC}_{50}$ values obtained in the above-mentioned tests, it can be seen that the examined compounds damaged the cell organelles in the following order: cell membrane, then mitochondrion and, finally, lysosomes. 
The carried out studies showed that cobalt chloride and chromium chloride caused a concentration-dependent decrease in cell viability in the MTT and NRU assays, with the exception of 100 and $200 \mu \mathrm{M}$ concentrations in which cell proliferation was observed. In the LDH assay, an increase in enzyme release (decreased cell viability) with an increase in the tested compound concentration was noted. The results were confirmed by other previous experiments in which WTHBF-6 cell lines were exposed to cobalt chloride, and a decrease of cell viability had been observed. Other studies reported that cobalt chloride caused a decrease in membrane potential and depletion of ATP in astrocytes [12]. The toxic effect of cobalt chloride was confirmed in studies conducted on the astrocyte line, where a decrease in cell viability was noted [41]. Toxicity of this element is probably due to its ability to generate reactive oxygen species.

Literature data clearly indicate that cobalt and chromium are cytotoxic metals. Cobalt generates reactive oxygen species that are highly destructive to molecules. Cobalt ions in the presence of hydrogen peroxide can increase the level of damage by activating the caspase system by reacting with hydrogen peroxide in the Fenton reaction [11,12,41-43]. One of the most dangerous effects of cobalt is the reduction of the membrane potential of the mitochondria and the peroxidation of the membrane lipids of these organelles [40,44,45]. Toxicity of cobalt may result from two mechanisms: from direct destruction by free radicals of biomolecules or from the destruction of the antioxidant system. Previous studies have shown changes in the activity of enzymes of antioxidant system in the liver cells of mice after exposure to cobalt chloride. An increase of GPx and a decrease of ACT and SOD were observed [42]. The decrease of activity of SOD enzyme is related to the binding of cobalt to the sites of zinc and copper in SOD, thus reducing the activity of the enzyme [36]. Moreover, the toxicity of cobalt could be related to its high affinity for sulfhydryl groups. Cobalt has influence upon the mitochondrion function because it causes inhibition of crucial enzymes in mitochondrial respiration [18].

The experiments carried out in this study also confirmed the toxic effect of chromium chloride. In our work, decrease of cell viability along with increased concentrations was noted; the exception was at 100 and $200 \mu \mathrm{M}$, when stimulation of cell proliferation was noted. This investigation was confirmed by earlier research carried out on the keratinocytes line, where decreased cell viability in the MTT assay was observed [26]. Moreover, other research was carried out on ovarian Chinese Hamster cells exposed to chromium chloride at the concentration of $1000 \mu \mathrm{M}$ or chromium picolinate (at a dose of $80 \mu \mathrm{g} / \mathrm{cm}^{2}$ ) in a colony formation test.

We also saw a decrease of cell viability and destruction in the mitochondrion structure. They were swollen with destruction of mitochondrial combs after exposure to chromium toxicity [46]. Studies by other authors indicated that chromium (III) compounds had the ability to generate reactive oxygen species, with a destructive effect on mitochondria and DNA, leading to apoptosis [47]. What is more, chromium (III) has a destructive effect on lipids, causing their peroxidation in liver and kidney cells [25]. As reported in the literature, chromium (III) has a destructive effect on the antioxidant system, which is unable to remove harmful forms during cell imbalance. A gradual increase in activity of CAT and GPx when compared to the control system was observed [48].

The interaction of the elements may be of different nature. In the case of reducing the effects of the examined elements, antagonism can be observed, and in the case of their intensification - synergism. During the simultaneous incubation with chromium chloride at the concentration of $200 \mu \mathrm{M}$ and cobalt chloride at the concentration of $1000 \mu \mathrm{M}$ of the BJ cells, antagonism was observed - chromium (III) at the concentration of $200 \mu \mathrm{M}$ served as protective function against the toxic concentration of cobalt (II) at the concentration of $1000 \mu \mathrm{M}$. These observations were made in the MTT and the NRU, where a statistically significant increase in viability of fibroblast cell was noted in comparison to the cells incubated with chromium chloride at the concentration of $1000 \mu \mathrm{M}$, and in the case of the LDH test, a decrease in enzyme release was observed. However, in the case of the interaction of chromium chloride with the concentration of $1000 \mu \mathrm{M}$ and cobalt chloride with the concentration of $200 \mu \mathrm{M}$, no protective effect of chromium chloride against cobalt chloride was observed. In this case, synergism was observed between the examined elements. Such observations were made in the case of cytotoxicity assays, where there was a decrease in cell viability in the MTT and NRU tests, and an increase in the release of the enzyme lactate dehydrogenase in the $\mathrm{LDH}$ test was noticed. The lack of protective effect of chromium chloride with the concentration of $1000 \mu \mathrm{M}$ is associated with a decrease in the efficiency of the antioxidant system [49]. These results are confirmed by another study conducted by Chen et al., in which enzymes of the antioxidant system (in a non-cellular system) were treated with chromium (III) in the range of 0 to $5.0 \times 10^{-4} \mathrm{~mol} \mathrm{l}^{-1}$. In low concentrations, i.e. $2.0 \times 10^{-4} \mathrm{~mol}$, chromium chloride was observed to increase catalase activity, which decreased at higher concentrations. The destructive effect was due to the destruction of the active center of this enzyme by chromium (III) [49].

The ability of low concentrations of chromium (III) to stimulate catalase activity results in its protective effect against the post-oxidative effect of cobalt (II) used in high concentrations. In the case of interaction of chromium chloride at the concentration of $1000 \mu \mathrm{M}$ and cobalt chloride at the concentration of $200 \mu \mathrm{M}$, no protective effect of chromium chloride against cobalt chloride was observed. In this case, synergism was observed between the studied elements. Such observations were made in the case of cytotoxicity tests, where a decrease in cell viability was noted in the MTT and NRU, while there was an increase in the release of the enzyme lactate dehydrogenase in the LDH test. The lack of protective effect of chromium chloride at the concentration of $1000 \mu \mathrm{M}$ is associated with the generation of oxygen free radicals and decreased efficiency of the antioxidant system [49]. In the case of interaction of chromium (III) at $1000 \mu \mathrm{M}$ concentration with cobalt chloride at $200 \mu \mathrm{M}$ concentration, the first element enhances the proapoptotic effect of cobalt (II).

\section{CONCLUSION}


Chromium (III) and cobalt (II) are trace elements required for good health, but their excess can cause toxic effects. These metals are commonly widespread. They are components in dietary supplements and energy drinks. In addition, they are components of biomaterials. According to several studies, the toxicity of the elements is dose-dependent. Cobalt and chromium have a destructive effect on the cell membrane, lysosomes and mitochondria, which leads to disorders of cell metabolism. In addition, the elements have the ability to generate reactive oxygen species that are destructive to cells. In our work, during the first interaction $(200 \mu \mathrm{M}$ of chromium chloride and $1000 \mu \mathrm{M}$ of cobalt chloride), antagonism was observed. However, in the case of the other interaction (chromium chloride at $1000 \mu \mathrm{M}$ and cobalt chloride at $200 \mu \mathrm{M}$ ), the protective effect of chromium chloride on cobalt chloride was not observed. In this case, synergism between these elements was noted.

\section{ORCID iDs}

Katarzyna Czarnek (Dhttps://orcid.org/0000-0002-7081-5526 Andrzej K. Siwicki (1)https://orcid.org/0000-0002-7372-2181

\section{REFERNCES}

1. Leggett RW. The biokinetics of inorganic cobalt in the human body. Sci Total Environ. 2008;289:259-69.

2. Bielański A. Podstawy chemii nieorganicznej. Warszawa 2014, Wydawnictwo Naukowe PWN.

3. Finley BL, Monnot AD, Paustenbach DJ, Gaffney SH. Derivation of a chronic oral reference dose for cobalt. Regul Toxicol Pharmacol. 2012;64:491-503.

4. Ren J, Zhang X, Wang G, Liu Y, Ren Y, Zhao Y, et al. Toxicity of nickel and cobalt in Japanese flounder. Environ Pollut. 2020;263B:114516.

5. Zhao Y, Cao Ch, Liu Y, Wang J, Li S, Li L, et al. Genetic analysis of oxidative and endoplasmic reticulum stress responses induced by cobalt toxicity in budding yeast. Biochim Biophys Acta Gen Subj. 2020;1864:129516.

6. De Boeck DM, Kirsch-Volders M, Lison D. Cobalt and antimony: Genotoxicity and carcinogenicity. Science and Direct. 2003;533:135-52.

7. Kabata-Pendias A, Pendias H. Biogeochemia pierwiastków śladowych. 1993, Wydawnictwo Naukowe PWN.

8. Simonsen LO, Brown AM, Harbak H, Kristensen BI, Bennekou P. Cobalt metabolism and toxicology - A brief update. Sci Total Environ. 2012;43:210-5.

9. Bresson C, Lamouroux C, Sandre C, Tabarant M, Gault N, Poncy $\mathrm{JL}$, et al. An interdisciplinary approach to investigate the impact of cobalt in a human keratinocyte cell line. Biochimie. 2008;88:1619-29.

10. Burgaz S, Demircigil GÇ, Yılmazer M, Erta N, Kemaloglu Y, Burgaz Y. Assessment of cytogenetic damage in lymphocytes and in exfoliated nasal cells of dental laboratory technicians exposed to chromium, cobalt, and nickel. Mutat Res Fund Mol Mech Mutagen. 2002;521:47-56.

11. Gault N, Sandre C, Poncy J-L, Moulin C, Lefaix J-L, Bresson C. Cobalt toxicity: chemical and radiological combined effects on HaCaT keratinocyte cell line. Toxicol Vitro. 2010;24:92-8.

12. Smith LJ, Holmes AL, Kandpal SK, Mason MD, Zheng T, Wise SP. The cytotoxicity and genotoxicity of soluble and particulate cobalt in human lung fibroblast cells. Toxicol Appl Pharmacol. 2014;278:259-65.

13. Klaunig JE, Pu ZWX, Zhou S. Oxidative stress and oxidative damage in chemical carcinogenesis. Toxicol Appl Pharmacol. 2011;254:86-99.

14. Lyons TJ, Nersissian A, Huang H, Yeom H, Nishida CR, Graden JA, et al. The metal binding properties of the zinc site of yeast copperzinc superoxide dismutase: implications for amyotrophic lateral sclerosis. JBIC. 2000;5:198-203.
15. Asmuss M, Mullenders LH, Eker A, Hartwig A. Differential effects of toxic metal compounds on the activities of Fpg and XPA, two zinc finger proteins involved in DNA repair. Carcinogenesis. 2000;21(11):2097-104.

16. Méplan C, Richard MJ, Hainaut P. Metalloregulation of the tumor suppressor protein p53: zinc mediates the renaturation of p53 after exposure to metal chelators in vitro and in intact cells. Oncogene. 2000:19(46) 5227-36.

17. Palecek E, Brazdova M, Cernocka H, Vlk D, Brazda V, Vojtesek B. Effect of transition metals on binding of $\mathrm{p} 53$ protein to supercoiled DNA and to consensus sequence in DNA fragments. Oncogene. 1999;18(24):3617-25.

18. Barceloux DG. Chromium. Clin Toxicol. 1999;37(2):173-94.

19. Lamson DW, Plaza SM. The safety and efficacy of high-dose chromium. Alternative Med Rev. 2002;7:3.

20. Pechova A, Pavlata P. Chromium as an essential nutrient: a review. Vet Med. 2007;52(1):1-18.

21. Unice KU, Monnot AD, Gaffney SH, Tvermoes BE, Thuett KA, Paustenbach DJ, et al. Inorganic cobalt supplementation: Prediction of cobalt levels in whole blood and urine using a biokinetic model. Food Chem Toxicol. 2012;50:2456-61.

22. Rocha JFX, Aires AR, Nunes MAG, Flores EMM, Kozloski GV, Vargas AC, et al. Metabolism, Intake, and Digestibility of Lambs Supplemented with Organic Chromium. Biol Trace Elem Res. 2013;156:130-3.

23. Hamilton EM, Youngb SD, Baileyb EH, Wattsa MJ. Chromium speciation in foodstuffs: A review. Food Chem. 2018;250:105-12.

24. Galaris D, Evangelou A. 2002, The role of oxidative stress in mechanisms of metal- induced carcinogenesis. Crit.Rev.Oncol. Hematol. 142: 93-103.

25. Hepburn DDD, Vincent JB. Tissue and subcellular distribution of chromium picolinate with time after entering the bloodstream. $J$ Inorg Biochem. 2003;94:86-93.

26. Shrivastava HY, Ravikumar T, Shanmugasundaram N, Babu M, Nair BU. Cytotoxicity studiem of chromiu (III) complexes on human dermal fibroblasts. Free Radic Biol Med. 2005;38:58-69.

27. Figgitt M, Newson N, Lesliec IJ, Fisher J, Ingham E, Case ChP. The genotoxicity of physiological concentrations of chromium (Cr (III) and $\mathrm{Cr}(\mathrm{VI})$ ) and cobalt (Co (II)): An in vitro study. Mutat Res. 2010;688:53-61.

28. Persson E, Henriksson J, Tjälve H. Uptake of cobalt from the nasal mucosa into the brain via olfactory pathways in rats. Toxicol Lett. 2003;145:19-27.

29. Garcia MG, Hura M, Chen J, Bhattia M. Cobalt toxic optic neuropathy and retinopathy: Case report and review of the literature. Am J Ophthalmology Case Reports. 2020;17:100606.

30. Lin H-Y, Bumgardner JD. In vitro biocorrosion of $\mathrm{Co}-\mathrm{Cr}-\mathrm{Mo}$ implant alloy by macrophage cells. J Orthop Res. 2004;22:1231-123.

31. Lucchetti MC, Fratto G, Valeriani F, De Vittori E, Giampaoli S, Papetti P, et al. Cobalt-chromium alloys in dentistry: An evaluation of metal ion release. J Prosthet Dent. 2015;114:602-8.

32. Lutz J, Díaz C, García J.A, Blawert C, Mändal S. Corrosion behaviour of medical CoCr alloy after nitrogen plasma immersion. Surf Coating Tech. 2011;205:3043-9.

33. Mobasheria A, Proudman CH.J, Cobalt chloride doping in racehorses: Concerns over a potentially lethal practice. Vet J. 2015;205:335-8.

34. Tvermoesa BE, Finley BL, Unicec KM, Otani JM, Paustenbach DJ, Galbraith DA. Cobalt whole blood concentrations in healthy adult male volunteers following two-weeks of ingesting a cobalt supplement. Food Chem Toxicol. 2013;53:417-24

35. Fathima A, Manikandamathavan VM, Jonnalagadda RR, Nair BU. Chromium-catechin complex, synthesis and toxicity check using bacterial models. Heliyon. 2020;6(8):E04563.

36. Król E, Krejpcio Z. Chromium (III) proprionate complex supplementation improves carbohydrate metabolism in insulinresistance rat model. Food Chem Toxicol. 2010;48:2791-6.

37. Lia P, Caoa Y, Songa G, Zhao B, Mac O, Lia Z. Anti-diabetic properties of genistein-chromium (III) complex in $\mathrm{db} / \mathrm{db}$ diabetic mice and its sub-acute toxicity evaluation in normal mice. J Trace Elem Med Biol. 2020;62:126606.

38. Vincent JB. The biochemistry of chromium. J Nutr. 2000;130:715-8. 
39. Ceriotti L, Pontia F, Broggi F, Kob A, Drechsler S, Thedinga E, et al. Real-time assessment of cytotoxicity by impedance measurement on a 96-well plate. Sensor Actuator B Chem. 2007;123:769-78.

40. Karovic O, Tonazzini I, Robola N, Edstrom E, Lovdahl C, Fredholm BB. Toxic effects of cobalt in primary cultures of mouse astrocytes. Similarities with hypoxia and role of HIF-1a. Biochem Pharmacol. 2007;73:694-708.

41. Christova TY, Gorneva GA, Taxirov SI, Duridanova B, Setchenska MS. Effect of cisplatin and cobalt chloride on antioxidant enzymes in the livers of Lewis lung carcinoma - Bering mice: protective role of heme oxygenase. Toxicol Lett. 2003;138:235-42.

42. Lison D. Cobalt Chapter 34. Hanbook on the Toxicology of metals. Elsevier 2015;743-763

43. Moriwaki H, Osborne MR, Phillips DH. Effects of mixing metal ions on oxidative DNA damage mediated by a Fenton-type reduction. Toxicology in Vitro. 2008;22:36-44.

44. Battaglia V, Compagnone A, Bandino A, Bragadin M, Rosii CA, Zanetti F, et al. Cobalt induces oxidative stress in isolated liver mitochondria responsible for permeability transition and intrinsic apoptosis in hepatocyte primary cultures. Int J Biochem Cell Biol. 2009; 41:586-94.
45. Mou YH, Yang JY, Cui N, Wang JM, Hou Y, Song S, et al. Effects of cobalt chloride on nitric oxide and cytokines/chemokines production in microglia. Int Immunopharm. 2012;13:120-5.

46. Manygoats KR, Yazzie M, Stearns DM. Ultrastructural damage in chromium picolinate-treated cells: a TEM study. J Biol Inorg Chem. 2002;7:791-8.

47. Staniek H, Kostrzewska-Poczekaj M, Arndt M, Szyfterb K, Krejpcio Z. Genotoxicity assessment of chromium (III) propionate complex in the rat model using the comet assay. Food Chem Toxicol. 2010;48:89-92.

48. Fleury C, Petita A, Mwalea A, Antonioua J, Zukora D.J, Tabrizianb M, et al. Effect of cobalt and chromium ions on human MG-63 osteoblasts in vitro: Morphology, cytotoxicity, and oxidative stress. Biomaterials. 2006;27:3351-60.

49. Chen L, Zhang J, Zhu Y, Zhang Y. Interaction of chromium (III) or chromium (VI) with catalase and its effect on the structure and function of catalase: An in vitro study. Food Chem. 2018;244:378-85. 